\title{
TAPCells, the Chilean dendritic cell vaccine against melanoma and prostate cancer
}

\author{
Flavio Salazar-Onfray ${ }^{1,2}$, Cristián Pereda ${ }^{1,2}$, Diego Reyes ${ }^{1,2,4}$, and Mercedes N. López ${ }^{1,2,3}$ \\ 1 Institute of Biomedical Sciences, Faculty of Medicine, University of Chile, 8380453 Santiago, Chile. \\ 2 Millennium Institute on Immunology and Immunotherapy, University of Chile, 8380453 Santiago, Chile. \\ 3 Cell Therapy Laboratory, Blood Bank Service, University of Chile Clinical Hospital, 8380453 Santiago, Chile. \\ ${ }^{4}$ Urology Service, University of Chile Clinical Hospital, 8380453 Santiago, Chile.
}

\begin{abstract}
Here we summarize 10 years of effort in the development of a biomedical innovation with global projections. This innovation consists of a novel method for the production of therapeutic dendritic-like cells called Tumor Antigen Presenting Cells (TAPCells ${ }^{\circledR}$ ). TAPCells-based immunotherapy was tested in more than 120 stage III and IV melanoma patients and 20 castration-resistant prostate cancer patients in a series of phase I and I/II clinical trials. TAPCells vaccines induced T cell-mediated memory immune responses that correlated with increased survival in melanoma patients and prolonged prostate-specific antigen doubling time in prostate cancer patients. Importantly, more than $60 \%$ of tested patients showed a Delayed Type Hypersensitivity (DTH) reaction against the lysates, indicating the development of anti-tumor immunological memory that correlates with clinical benefits. The in vitro analysis of the lysate mix showed that it contains damage-associated molecular patterns such as HMBG-1 protein which are capable to improve, through Toll-like receptor-4, maturation and antigen cross-presentation of the dendritic cells (DC). In fact, a Toll-like receptor-4 polymorphism correlates with patient clinical outcomes. Moreover, Concholepas concholepas hemocyanin $(\mathrm{CCH})$ used as adjuvant proved to be safe and capable of enhancing the immunological response. Furthermore, we observed that DC vaccination resulted in a three-fold increase of T helper-1 lymphocytes releasing IFN- $\gamma$ and a two-fold increase of T helper-17 lymphocytes capable of producing IL-17 in DTH+ with respect to DTH- patients. Important steps have been accomplished for TAPCells technology transfer, including patenting, packaging and technology assessment. Altogether, our results indicate that TAPCells vaccines constitute an exceptional Chilean national innovation of international value.
\end{abstract}

Key words: Dendritic Cells, Cancer Immunotherapy, Melanoma Vaccine, Technology Transfer, Biotechnology.

Innovation in biomedicine refers to the creation of a new and unique product whose use should result in the creation of an economic or social value. Recent biomedical innovations cover a large spectrum of applications, ranging from the use of computed tomography and magnetic resonance imaging to the utilization of biological drugs such as growth factors, protein analogues, inhibitors of serotonin reuptake, innovative treatments for cataracts and lens implants. These innovations are part of a global market of enormous magnitude. The pharmaceutical industry reached an overall size of 955,000 million dollars in 2011 and its compound annual growth rate for the upcoming years is estimated to be 3-6\% (IMS, 2012). The share of Latin America in this market is only $7 \%$, but with a projected annual growth rate of 10-13\% in 2016 (IMS, 2012).

Despite the importance of social welfare, innovation in health is not free of difficulties, particularly in a middleincome country like Chile. Very few examples of successful innovation in the field of health are recorded in our history, with the notable exception of the creation of the National Health Service. A significant difficulty is the fact that diagnostic or therapeutic innovations involve clinical trials of high costs and long time, including assessments of long-term efficiency and security. Furthermore, research in humans has been the subject of sustained discussion due to new ethical dilemmas such as the use of embryonic stem cells or personal genetic information. In this paper we summarize 10 years of experience in the development of an innovation in biomedicine with global projections.

\section{CANCER, A PUBLIC HEALTH PROBLEM IN CHILE}

One of the main causes of death in the developed world is cancer. In our country, this group of diseases constitutes the second leading cause of death in the population over age 20 years. In 1970 cancer related mortality accounted for $12.1 \%$ of deaths in Chile; in 1990 it increased to $18.1 \%$ and in 2005 it rose to $24.8 \%$ (Ferlay et al., 2010). These rates, which correlate with the stage of development and life expectancy of each country, are higher than the average for the rest of Latin American countries (74 deaths per 100,000 population) (Ferlay et al., 2010); and thus show the need to establish cutting-edge treatments using advanced techniques to fight oncological diseases. In our country, the tumors with greatest clinical and socioeconomic impact are prostate cancer, breast cancer, colorectal cancer and biliary-digestive tumors, corresponding to the vast majority of deaths due to malignant tumors; to which malignant melanoma must be added, a tumor that shows the highest incidence growth in Chile (Ferlay et al., 2010). Current treatments such as chemotherapy and radiotherapy have shown beneficial effects in some cancers, particularly in those of hematopoietic origin (Nieboer et al., 2005; Hayat et al., 2007), but its effects have been limited in other solid tumors. Since tumor recurrence is a common event in patients treated by surgery, it is imperative to generate more effective therapeutic interventions that are less invasive and with fewer adverse effects. One of these strategies involves the 
use of the immune system to fight cancer, which is known as cancer immunotherapy (López et al., 2004; Weiner, 2008).

\section{MELANOMA AND PROSTATE CANCER}

According to $\mathrm{WHO}$, the number of cases of melanoma has maintained a constant increase, more than any other cancer, affecting more than 2.4 million people worldwide, with an incidence of 150,000 new cases diagnosed each year (Lens, 2004). Despite improvements in survival rates, mortality from this skin cancer continues to rise and will become a major public health problem in the near future. In Chile, between 1990 and 2004 there were 3,287 deaths due to this cancer, and its incidence increased from 1.1 in 1990 to 1.8 cases per 100,000 people in 2004 (IMS, 2012). About 95\% of patients who are diagnosed early can survive through appropriate surgical treatments, however, once the tumor invades other tissues conventional therapies such as surgery, radiation, or chemotherapy are not curative in most cases.

Prostate cancer is a common malignant disease in men around the world. Only in the United States the number of new cases is estimated at 192,280, causing 27,360 deaths per year (Jemal et al., 2008). The 5-year survival of localized prostate cancer is almost $100 \%$, while patients with disseminated disease have a survival rate reduced to 53\% (Rini et al., 2006). Although the identification of the prostate-specific antigen (PSA) has improved the early detection of localized tumors (Bradford et al., 2006), prostate cancer is still the second leading cause of death due to cancer. In the event of an advanced form of the disease, the most standard treatment is androgen deprivation therapy (ADT). However, a significant percentage of these patients develop resistance within two years to the ADT, suffering rapid tumor progression (Garnick, 1993; Scher et al, 1995). At this stage chemotherapeutic agents such as Docetaxel are used. Although there is a limited increase in survival, therapy with this and other drugs cause side effects that some patients cannot manage (Tannock et al., 2004).

These facts confirm the need to explore new therapeutic approaches in melanoma and prostate cancer patients, particularly those related to the manipulation of the immune response against tumors. During the past 10 years, interaction between basic immunologists, clinicians and oncologists has facilitated a major international contribution to basic immunology and the development of cancer immunotherapy by our research group (López et al., 2004; Escobar et al., 2005; López et al., 2006; Salazar-Onfray et al., 2008; López et al., 2009; Aguilera et al., 2011; Tittarelli et al., 2012; Durán et al., 2012; Reyes et al., 2013).

\section{ANTITUMOR IMMUNOTHERAPY}

Understanding the relationship between the immune system and cancer began formally in the late nineteenth century, when the association between inflammation against pathogens and its effect against tumors was established (Pain, 2002). Decades of studies using animal models led to the immunosurveillance theory, which postulated that tumor cells could be recognized and destroyed by the immune system (Burnet, 1957). Twenty years ago it was demonstrated that endogenously produced interferon- $\gamma($ IFN- $\gamma)$ was able to protect the host against tumor growth (Dighe et al., 1994; Kaplan et al., 1998). In addition, mice lacking perforin, a key component of the cytotoxic granules from both CD8+ T lymphocytes (TL) and Natural Killer cells were shown to be more likely to develop spontaneous and chemical carcinogen-induced tumors (Thomas, 1982). These findings and the isolation of cytotoxic $\mathrm{T}$ lymphocytes with antitumor activity have increased the interest in using the immune system as a tool in the treatment of cancer (Viret et al., 1993; Knuth et al., 1992).

The accumulated evidence indicates that cancer patients can develop TL able to specifically recognize and destroy tumors in vitro (Itoh et al, 1998; Topalian et al., 1989). The TL are able to proliferate in response to stimulation with autologous tumor cells by secreting cytokines such as interleukin 2 (IL-2), interferon gamma (IFN- $\gamma$ ), granulocyte-macrophage colony stimulating factor and tumor necrosis factor alpha (TNF- $\alpha$ ) (Barth et al., 1991). These observations have resulted in the identification and characterization of tumor antigens recognized by human T cells (Boon et al., 1994; Boon et al., 1995).

From these findings, recombinant cytokines such as IL-2, IFN- $\gamma$ and IFN- $\alpha$ have been used as an adjuvant therapy in some cancers (Agarwala et al., 2002; Bajetta et al., 1994; Falkson et al., 1998; Keilholz et al., 2005). These cytokines have been used alone or in combination with chemotherapeutic agents such as dacarbazine (DTIC), showing utility for the control of metastasis in selected cases without increasing the survival of treated patients and with a high cost in terms of quality of life (Agarwala et al., 2002; Bajetta et al., 1994; Falkson et al., 1998; Keilholz et al., 2005). Adaptive therapies using TL stimulated in vitro have been tested in several protocols, with variable clinical responses (Rosenberg et al., 2008; Mackensen et al., 2006; Powell et al., 2006). The adoptive transfer of specific CD8+ TL against tumor antigens, with or without systemic immunosuppression, has also been used clinically, showing significant tumor reductions in some cases, but sometimes associated with undesirable side effects (Rosenberg et al., 2008; Mackensen et al., 2006; Powell et al., 2006).

Recently, new therapeutic targets have been identified in tumor cells (melanoma and breast cancer) and in the immune system, which has allowed the development of monoclonal antibodies with the aim to modulate the antitumor immune response and eliminate tumors (Vogel et al., 2002; Ribas et al., 2005). In the past two years the FDA approved two new biological approaches for the treatment of melanoma. Ipilimumab (Yervoy ${ }^{\circledR}$ ) is a monoclonal antibody against the immune regulator CTLA-4, recently approved for the treatment of patients with metastatic melanoma as a second line treatment after chemotherapy (Hodi et al., 2010). The estimated survival rates for patients treated with ipilimumab after one and two years were about double compared to the control group. However, the toxicity and described side effects requires prepared intermediate care units (Ma et al., 2013).

The approval of new biological drugs for the treatment of cancer during the past year has generated major interest, but also increased concern because of their high cost. The cost of the ipilimumab or the growth factor inhibitor vemurafenib for melanoma treatment is around US\$ 80,000 or more, approximately the same as sipuleucel-T (Provenge), a new cell therapy to treat metastatic prostate cancer.

\section{DENDRITIC CELLS AS CANCER VACCINES}

The capacity to activate specific TL against tumor cells in vivo requires a previous antigen presentation in a particular cell 
context. Professional antigen-presenting cells (APCs), among which the dendritic cells (DCs) stand out, are characterized by a functional plasticity that dictates the result of the innate and adaptive immune response (Hart, 1997; Bell et al., 1999).

DCs are located in diverse epithelia and mucosa and are continuously recirculating through the lymphoid tissues and organs, hence capturing innocuous self-antigens and proteins from the environment and thereby contributing to the maintenance of peripheral tolerance (Bonasio and von Andrian, 2006). In these tissues they can receive danger signals from the microenvironment known as damageassociated molecular patterns (DAMPs), induced by stress or tumor cell death (Matzinger, 2007; Sauter et al., 2000). When DCs acquire tumor antigens, they mature and migrate to secondary lymphoid organs where they deliver the signals to $\mathrm{TL}$, inducing their activation, proliferation, and migration to peripheral tissues to eliminate tumor cells. When properly stimulated in the periphery DCs are able to express costimulatory molecules, secrete cytokines and transfer other signals that are crucial to ensure the effectiveness of TLmediated antitumor response, favoring the best way for destruction of tumors (Ardavin et al., 2004; Shuler et al., 2003).

Thus autologous DCs loaded with tumor-associated antigens have become one of the most promising immunological tools for cancer therapy. These cells are naturally able to stimulate the antitumor immune response, generating immunological memory in the course of this response (Porgador and Gilboa, 1995; Paglia et al., 1996; Hart, 1997). Clinical trials demonstrate the possibility of using DCs loaded with antigenic peptides to induce peptide-specific TL responses in patients with lymphoma, malignant melanoma, and prostate cancer (Boczkowski et al. 1996; Nestle et al., 1998; Svane et al., 2003).

In general, clinical studies have been quite successful in inducing immunity against the tumor, but have shown minimal clinical impact (Boczkowski et al., 1996; Nestle et al., 1998; Rosenberg et al., 1998; Svane et al., 2003; Ridgway, 2003; Schadendorf et al., 2006). The optimal delivery of tumor antigen is one of the most important factors for the success of cancer vaccines. Lysates from allogeneic tumor cells, whole tumor cells, tumor mRNA and antigenic peptides have been tested as tumor vaccines. (Boczkowski et al., 1996; Nestle et al., 1998; Rosenberg et al., 1998; Svane et al., 2003; Ridgway, 2003; Schadendorf et al., 2006). As an alternative, DCs pulsed or loaded with tumors or tumor lysates from the same patient have been used to induce stronger and longer immune responses against tumors (O’Rourke et al., 2003; Nagayama et al., 2003; Hersey et al., 2004; Trefzer et al., 2005). This strategy has the advantage of providing tumor antigens capable of being presented in MHC class I and class II molecules by DCs, thus reducing the tumor escape. Nonetheless, the application of these approaches is limited to a smaller proportion of patients with operable tumors, leaving this therapy out of reach for patients with unresectable metastases, micrometastases and a high risk of recurrence.

\section{TAPCELLS; THE CHILEAN RESEARCH PROGRAM}

Our group solved these difficulties by using two unique techniques. The first innovation generated by our studies was the development of a generic antigenic pool derived from human metastatic melanoma cell lines named TRIMEL ${ }^{\circledR}$, which showed a very diverse antigenic repertoire (López et al., 2009; Aguilera et al., 2011). With this technological improvement, scientists from the University of Chile were able to make the treatment not dependent on the existence of autologous tumor cells. This generic cell preparation does not require the presence of the patient's tumor for vaccine manufacture. The results obtained by our research show that DCs pulsed or loaded with TRIMEL include all the necessary elements to induce a vigorous immune response, promoting the recognition and destruction of tumors in vitro and the stabilization of the disease in a portion of treated patients. This innovation puts this technology in a unique perspective for universal use, augmenting the possibility for potential global commercialization.

The second innovation developed by our group was biotechnological; it consisted of a rapid method for the preparation of DCs capable of capturing and presenting tumor antigens to the effector components of the immune response (López et al., 2009; Aguilera et al., 2011). By obtaining monocytes, a population of very common cells taken from the patient's blood, we were able, through cell culture techniques and the use of cytokines and the aforementioned TRIMEL, to prepare antigen-presenting cells in about 48 hours (López et al., 2009; Aguilera et al., 2011). These cells are then subjected to an additional cell activation process, which allows obtaining DCs with increased potency for induction of an anti-tumor immune response in patients (López et al., 2009; Aguilera et al., 2011; Reyes et al., 2013). This in itself is a great advantage over other methods that use precursors from DCs obtained from blood, because the majority of these methods take 5-9 days to generate a sufficient number of these cells.

These cells, known as Tumor-Antigen-Presenting-Cells (TAPCells ${ }^{\circledR}$ ), are able to generate an immune response that has been shown to specifically activate TL. TLs can then recognize the tumor cells and cause their destruction. This procedure and its components (Figure 1) are protected by an international patent application (Salazar-Onfray et al., 2008), which has already been awarded in Australia, New Zealand and in Mexico and is pending in another 10 countries.

Accordingly, using the international experience and our own scientific advances, we decided in 2003 to start phase I and II clinical trials, funded by the National Research and Development Agency FONDEF and approved by the Bioethics Committee for human studies of the Faculty of Medicine and the Clinical Hospital of the University of Chile. In these studies, TAPCells pulsed or loaded with allogeneic tumor lysates were used, as reported, in advanced melanoma and castration-resistant prostate cancer patients (Escobar et al., 2005; López et al., 2009; Aguilera et al., 2011; Reyes et al., 2013). An essential part of this process is the use of TRIMEL allogeneic cell lysate (López et al., 2009; Aguilera et al., 2011). TRIMEL has been characterized from an antigenic point of view, demonstrating the presence of most of the melanomaassociated antigens currently described (López et al., 2009; Aguilera et al., 2011). Additionally, it has been shown that TRIMEL is capable of inducing the maturation of DCs in the absence of pro-inflammatory cytokines such as TNF- $\alpha$ or IFN- $\alpha$, and without the necessity of additional stimulus (Aguilera et al., 2011; Reyes et al., 2013). This tumor lysate can then act not only as a source of antigen for DCs, but also as an inducer of their activation. Cells constituting the lysate were previously subjected to conditioning steps that include a heat shock. This heat shock consists of exposing the cells 


\section{TAPCells production process and treatment schedule}

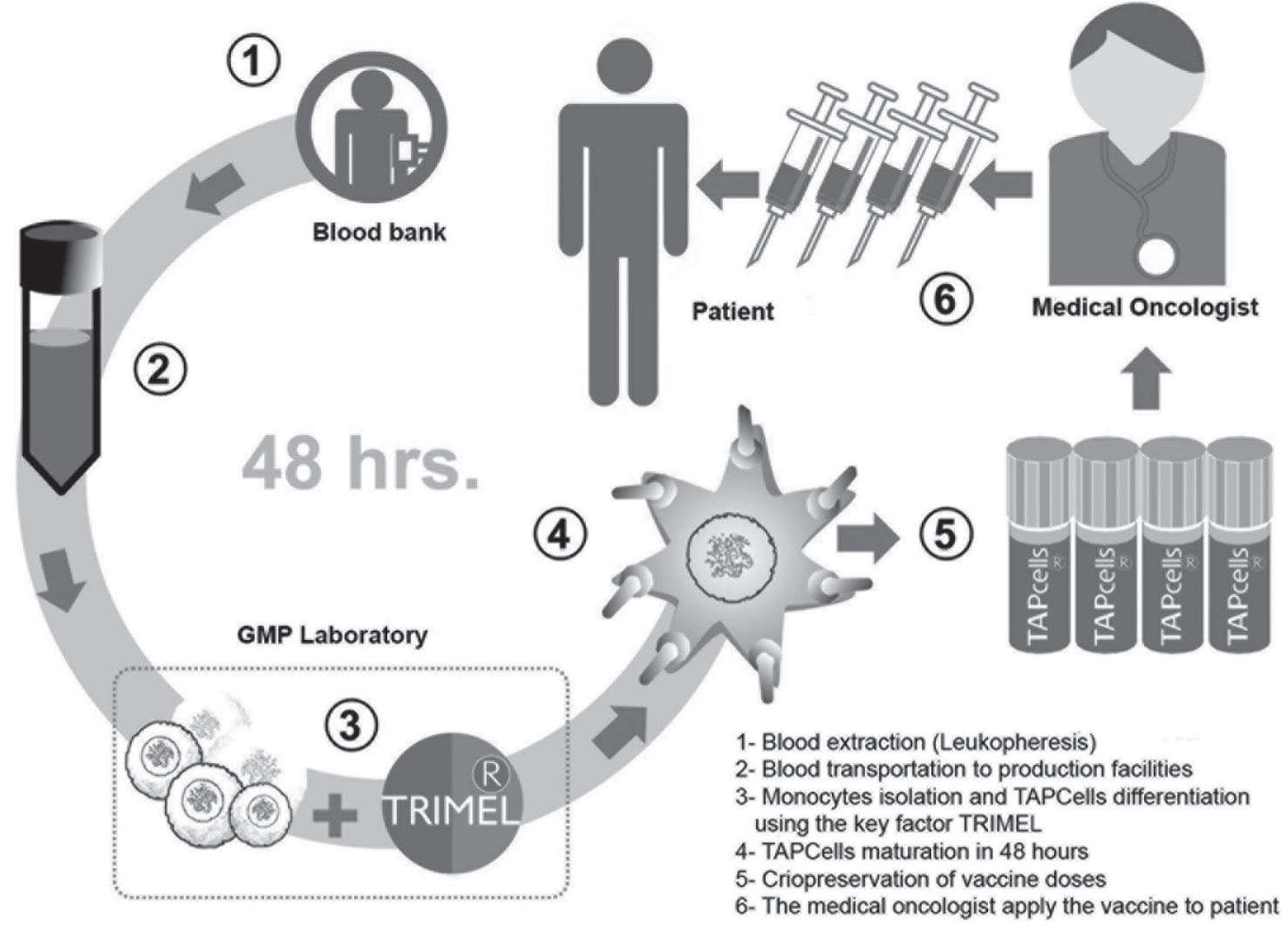

Figure 1. TAPCells production process and treatment schedule. Peripheral blood leucocytes are obtained from cancer patients by a leukapheresis process. Monocytes are separated by adherence and cultured with cytokine factors and after $24 \mathrm{~h}$ TRIMEL is added to cultures. After $48 \mathrm{~h}$, the TAPCells are cryopreserved and transported to the clinic where the physician treats patients.

to temperatures of $42{ }^{\circ} \mathrm{C}$ for a period of 1 hour and then 2 hours at physiological temperature $\left(37^{\circ} \mathrm{C}\right)$. Our data indicate that this conditioning of tumor cells from which the lysate is produced triggers danger signals that are essential to activate DCs and enhance antitumor signals to TL (Aguilera et al., 2011; Tittarelli et al., 2012; Reyes et al., 2013).

\section{THE CHILEAN VACCINE AGAINST MELANOMA: CLINICAL RESULTS}

First we carried out a phase I study that included 20 patients with metastatic malignant melanoma, which demonstrated that TAPCells alone could generate similar immune responses with fewer side effects than those combined with recombinant IL-2 cytokine (Escobar et al., 2005). A significant increase was observed in the specific IFN- $\gamma$ production in immunized patients' blood after treatment. In addition, for the first time a significant correlation between specific delayed type hypersensitivity (DTH) positive reaction against tumor antigens was reported, and an increase of short-term progression-free survival after vaccination (Escobar et al., 2005). In a series of phase I / II clinical trials, which included monitoring and clinical evaluation of 119 patients, it was found that TAPCells-based immunotherapy induced specific immune responses against the tumor mediated by TL and was associated with improved long-term survival of stage IV melanoma patients (Escobar et al., 2005; López et al., 2009;
Aguilera et al., 2011). Importantly, $60 \%$ of evaluated metastatic patients (62 of 102) developed a DTH reaction against TRIMEL, indicating the development of immunological memory against the tumor that correlates with prolonged survival of patients. The in vitro analysis of TRIMEL revealed that it contains DAMPs such as nuclear protein HMGB-1 induced by heat shock, which are capable of eliciting, through Toll-like receptors the maturation of DCs, improving TAA cross-presentation (Aguilera et al., 2011; Tittarelli et al., 2012). Tissue biopsies from DTH sites revealed the presence of $\mathrm{CD}_{4} \mathrm{RO}^{+} \mathrm{CD}^{+}$and $\mathrm{CD} 4^{+} \mathrm{TL}$ able to release pro-inflammatory cytokines after in vitro stimulation. The DTH response against TRIMEL, detected as a specific inflammation and local edema against exposed antigens, was associated with prolonged survival of responder patients (DTH+, 33 months) compared to non-responders (DTH-, 11 months). Additionally, 70\% of stage III melanoma vaccinated patients $(n=22)$ developed long-term stable disease with no signs of disease progression (López et al., 2009; Aguilera et al., 2011). It was also observed that vaccination with TAPCells resulted in a three-fold increase of the population of IFN- $\gamma$-producing T helper- 1 cells and a twofold increase of the $\mathrm{T}$ helper-17 population able to produce IL17 in the blood of DTH+ patients, compared to DTH- patients (Durán et al., 2013). Furthermore, the presence of T helper-1/ $\mathrm{T}$ helper-17 lymphocytes in the DTH reaction site was also confirmed by immunofluorescence and in vitro activation assays (Durán et al., 2013). Taken together, our results 
indicated that immunization with TAPCells resulted in two different patterns of immune responses associated with clinical outcomes. TAPCells treatment induced cellular immune responses, decreasing by more than $70 \%$ five-year mortality risk for patients with stage IV melanoma (Table 1).

THE CHILEAN VACCINE AGAINST PROSTATE CANCER: RESULTS

In a further phase I study performed at the University of Chile in patients with prostate cancer and in a recent report (Reyes et al., 2013), it was observed that there was a similar proportion of $\mathrm{DTH}+$ responders against a prostate cancer cell lysate (PCCL). In this study we associated the induction of DTH against PCCL with the generation and activation of clinically relevant memory $\mathrm{CD}^{+}$and $\mathrm{CD} 8^{+}$TLs (Table 1 ).

While the main aim of this phase I trial was the induction of specific immune response, a biochemical response could also be observed in 6 out of 14 patients, who showed a significant decrease in PSA serum levels $(30 \%$ or more from the baseline) compared to previous studies using antigenpresenting cells loaded with different antigen sources (such as peptides, proteins or mRNA), which reported reductions in serum PSA levels only sporadically (Tjoa et al., 1999; $\mathrm{Mu}$ et al., 2005; Fuessel et al., 2006). However, due to the heterogeneity of our patient cohort, we could not discount that the different stages and PSA levels before the treatment may have influenced the observed biochemical responses. Although survival was not evaluated in this study, there was an improvement in the serum PSA doubling time (PSADT) in immune-responder patients (Reyes et al., 2013). PSADT is a known prognostic factor that correlates with the outcome and overall survival of prostate cancer patients (Semeniuk et al., 2006). In conclusion, this study suggested that TAPCells-based immunotherapy against prostate cancer is a safe approach capable of inducing memory TL as determined in vivo (DTH) and in vitro (cytokine release), and that might be associated with clinical responses including the decrease in serum PSA levels and increase of the PSADT, which encourages continuing subsequent studies (Reyes et al., 2013).

Another important contribution was the validation of a new vaccine adjuvant developed in Chile. According to accumulated evidence, adjuvant properties are fundamental for the generation of a correct inflammatory environment for the induction of an immune response. In the melanoma studies it was shown that Keyhole Limpet hemocyanin is a potent inducer of immunogenicity (López et al., 2009; Aguilera et al., 2011). In the prostate studies, the Chilean Concholepas concholepas hemocyanin (CCH) (De Ioannes et al., 2004) was used for the first time as an adjuvant in a vaccine against cancer. In this clinical study, the $\mathrm{CCH}$ was able to induce an immune memory response as measured by the DTH test, and was found to generate no toxic or allergic reactions associated with its subcutaneous administration. Therefore $\mathrm{CCH}$ can be considered as an alternative to Keyhole Limpet hemocyanin in order to provide safe and effective adjuvanticity in cancer vaccines (Reyes et al., 2013).

TABLE 1

Clinical and immunological benefits for TAPCells treated patients

\begin{tabular}{l}
\hline Melanoma phase I and phase I/II clinical trials \\
\hline Approximately $60 \%$ of stage IV melanoma patients showed an immunological response against melanoma reflected in \\
a delayed type hypersensitivity reaction against melanoma-associated antigens present in TRIMEL. \\
A three-fold overall survival increase was observed in the DTH+ patients reaching 33 months post vaccine survival in \\
DTH+ patients compared with 8-10 months of historical survival of stage IV melanoma patients. \\
Almost $80 \%$ of stage IIIc high-risk melanoma patients treated with TAPCells remained free of new metastasis after 5 \\
years compared to a recurrence rate and death after 24 months of 70\% of untreated patients, or patients treated with \\
standard therapy. \\
The majority of treated patients did not show side effects. Only limited effects, related to local inflammation, low fever \\
and pain in the inoculation site have been reported after treatment. Vitiligo (skin depigmentation) associated with a \\
positive immune response has been observed in some patients. \\
An induction of an antitumor immune profile of T cell subpopulations Th1 and Th17, and a reduced regulatory \\
population Th3, have been detected in DTH+ responder patients. \\
Prostate cancer phase I clinical trial \\
Approximately $60 \%$ of castration-resistant prostate cancer patients showed an immunological response against \\
tumors, reflected in a delayed type hypersensitivity reaction against prostate-associated antigens present in the \\
prostate tumor cell lysate. \\
An increase in memory CD8+ T cells was detected in DTH+ patients after vaccine. \\
Concholepas concholepas hemocyanin (CCH), used for the first time as an adjuvant in a cancer vaccine, was able to \\
induce an immune memory response as measured by the DTH test, and was found to generate no toxic or allergic \\
reactions associated with its subcutaneous administration. \\
A biochemical response, significant decrease in PSA serum levels and improvement in the serum PSA doubling time \\
(PSADT) were observed in immune-responder patients, an improvement over previous studies that only reported \\
reductions in serum PSA levels in limited cases. \\
No side effects were observed due the vaccine and no effects on quality of life were reported. \\
\hline
\end{tabular}


Finally, it is very important to highlight that no severe adverse events related to treatment (grade 3 or higher) were observed in the melanoma or prostate cancer trials (López et al., 2009; Reyes et al., 2013). In fact, the few adverse events reported in these studies were inflammatory skin reactions at the site of inoculation, which correlated with a positive DTH-test at the end of the study. Similarly, although the overall health status and functional scores of the treated patients did not improve, they remained stable during treatment (Reyes et al., 2013).

\section{TECHNOLOGY TRANSFER OF TAPCELLS; ONCOBIOMED}

Based on the progress achieved by our research team, the R\&D Company Oncobiomed was founded in 2002 by academics and researchers from the University of Chile, together with experts in the business area. According to its own description, Oncobiomed is oriented to develop, commercialize, transfer, and license technologies associated with the prevention, diagnosis and treatment of cancer. The work of this team achieved the formalization of a company that combines scientific, technological, commercial, and legal aspects supported by solid scientific publications and concrete clinical results, all protected worldwide by a patent (Salazar-Onfray et al., 2008).

The enterprise's initial funding came from the government through various agencies such as FONDEF (US\$ 2.5 million) and CORFO (US\$ 1 million). Currently the company is valued at approximately US\$10 million and has established a clinic for the treatment of patients with advanced melanoma in Santiago. These innovative treatments have helped more than 250 patients and the economic returns of the venture have been reinvested in the technology transfer of the project and in financing the treatment of some patients. The cost per patient is five times less than that of other available treatments, which are less effective. The economic benefit, calculated as the increase in years of life, increased productivity, and savings in health care costs, has been estimated at US\$ 2 million/year for the domestic market and a projected value for the international market of US\$ 600 million.

Oncobiomed is close to establishing a licensing agreement with the University of Chile, owner of the TAPCells technology. In addition to a dynamic research line in cell therapy the company has expanded, developing other 3 business lines. By the year 2010, Oncobiomed was recognized internationally as an innovative entrepreneurship leader in Latin America; winning the "Tres Mares Innovation Prize" from the Americas Venture Capital Conference investment fund in Miami, USA. Additionally, The investment fund Farmainnova appointed Oncobiomed as the first candidate for private funding among 77 proposals, supporting the potential technological and commercial impact of the company.

\section{R\&D PROJECTIONS}

Our studies have shown promising effects of TAPCells in patients with malignant melanoma and prostate carcinoma (Escobar et al., 2005; López et al., 2009; Aguilera et al., 2011; Reyes et al., 2013). Despite the significant progress achieved, the induced clinical responses in patients are still insufficient. A significant proportion of patients $(40 \%)$ do not respond, or their immunological and clinical responses are too weak or less durable (Escobar et al., 2005; López et al., 2009; Aguilera et al., 2011; Reyes et al., 2013). There are several explanations for these results; for example, the described clinical studies have shown that patients have different immune response profiles associated with particular clinical outcomes (López et al., 2009; Durán et al., 2013). Recent evaluations of our patients show that individuals with high proportions of $\mathrm{T}$ helper-1 and $\mathrm{T}$ helper-17 lymphocytes and low proportions of TGF- $\beta$ producing $\mathrm{T}$ cells after immunization and have a median survival longer than those patients with the opposite pattern of cytokine response (López et al., 2009; Durán et al., 2013).

Nevertheless, objective clinical responses in vaccinated patients are still insufficient. Regulation of the immunological response by inhibitory cells could be a possible cause of clinical unresponsiveness (López et al., 2006). Lately, the existence of subpopulations of regulatory $\mathrm{T}$ lymphocytes able to limit the immune response in a specific form has been established, particularly inhibiting the proliferation and activity of CD4+ and CD8+ effector TL (Sakaguchi, N. 2005). These cellular subpopulations, mostly CD4+/CD25+/ Foxp3+ T lymphocytes of thymic origin, or regulatory TL able to release IL-10 and TGF- $\beta$, would be accumulated in the body during tumor growth, inhibiting the immune response (Sakaguchi, N., 2005; López et al., 2006). In relation to regulatory TL and cancer, evidence indicates that these cells are augmented in blood and other tissues in different types of cancer (Wolf AM et al., 2003; Curiel TJ et al., 2004). Additionally, it has been demonstrated that in patients with refractory metastatic melanoma, the adoptive transference of anti-tumor CD8+ T lymphocytes after non-myeloablative chemotherapy was able to induce important tumor regressions that would be due to elimination of regulatory TL populations (Dudley M.E. et al., 2005).

Another possibility is given by the myeloid-derived suppressor cells (MDSC), which are potent immune regulators with a broad arsenal of suppressive mechanisms; they are key players in tumor-induced suppression of T-cell responses (Youn JI et al., 2010; Peranzoni E et al., 2010). By definition they are a heterogeneous population of immature, immunosuppressive cells of myeloid origin, containing dendritic cell, macrophage and granulocyte precursors that regulate the immune responses to infection and after traumatic stress (Cuenca AG et al., 2011). Increased frequencies of CD14+HLA-DR-/low immature myeloid cells with suppressive functions have been observed in many different types of cancer, including melanoma (Filipazzi P et al., 2007; Gustafson MP et al. 2010; Lin Y et al., 2010; and Vuk-Pavlovic $S$ et al., 2011).

MDSC are known to be impaired in their ability to differentiate along the myeloid lineage, e.g., into dendritic cells (DC). This is a concern for the utilization of monocytederived DC for vaccination of cancer patients who exhibit an accumulation of CD14+ MDSC. In fact, when producing DC according to standard procedures in our clinical trials, we found that MDSC co-purified with the isolated monocytes (Poschke I et al., 2012). MDSC frequencies did not affect yield or viability of the produced DC, but induced a dose-dependent decrease in DC maturation, ability to take up antigen, migrate and induce T-cell IFN- $\gamma$ production (Poschke I et al., 2012).

Since the presence of HLA-DR- cells in starting cultures could affect DC vaccines by inhibiting the migratory capacity of DCs, we propose that DC preparations where CD14+HLADR- MDSC are known to occur will profit from monitoring of this cell population. In some cases removal of HLA-DR- 
cells by positive selection of CD14+HLA-DR+ cells should be beneficial. Unfortunately, fluorescence-assisted cell sorting or magnetic bead isolation methods are cost-intensive to apply under conditions of clinical grade DC production and potentially can modify cellular activation status.

In parallel, it was also observed that patients who express a polymorphic allele of the Toll-like receptor-4 receptor showed lower survival; demonstrating the importance of understanding the genetic basis of patients and associating it with the potential prognosis (Tittarelli et al., 2012).

The determination of the immunologic and genetic characteristics of evaluated metastatic patients before treatment and the identification of monitoring parameters will significantly increase the value of the technology and will facilitate its incorporation in the arsenal of cancer treatments. Moreover, the effect of tumor cell stress in enhancing the immune response strongly suggests that immunotherapy should be combined with chemotherapy or radiation therapy, both of which destroy the integrity of tumors and possibly increase the danger signals necessary for an optimal immune response.

\section{CONCLUSIONS}

Based on the available data with respect to the cost and effectiveness of cancer gold standard therapies, and on the belief that this disease, besides being a distressing health problem also means an economic disaster for the patient, family, and society in Latin America (Goss et al., 2013). Moreover, the treatment implemented by the Chilean vaccine program has shown high curative efficiency in practice and an attractive price/quality ratio; this allows proposing this immunotherapy as an alternative complementary treatment which is not only less costly and without side effects, but also more efficient and complementary to standard treatments.

From the perspective of using the technology worldwide, the results of clinical phases I and I/II conducted in Chile showed a clear improvement in melanoma patient survival, whereas in prostate cancer patients the results also seem to be clearly promising. However, to ensure the internationalization of the technology it is mandatory to perform phase III multi-center clinical trials (randomized over 200 welldefined patients) that compare TAPCells with gold standard treatments with dacarbazine or Ipilimumab. This type of study should be conducted by certified entities in developed countries such as USA, Australia, or Europe under strict regulatory standards. The cost of these trials is estimated in the range of US\$ 25 to 100 million, depending on the final cost of several parameters, among which is the prevalence of the disease in the chosen country (Figure 2).

A detected weakness of the TAPCells technology is the low standardization of the production process of tumor lysates. Technology internationalization requires highly reproducible processes, including potency assays and stringent quality control of all of the process components. To solve this problem we recently started a new R\&D FONDEF project, trying to achieve the standardization of the production processes for TRIMEL and other immunogenic tumor compounds. These compounds will facilitate the production of TAPCells potentially useful in a wide variety of other neoplastic diseases. Finally, it is necessary to design R\&D strategies that advance new antigenic products for future application in high-

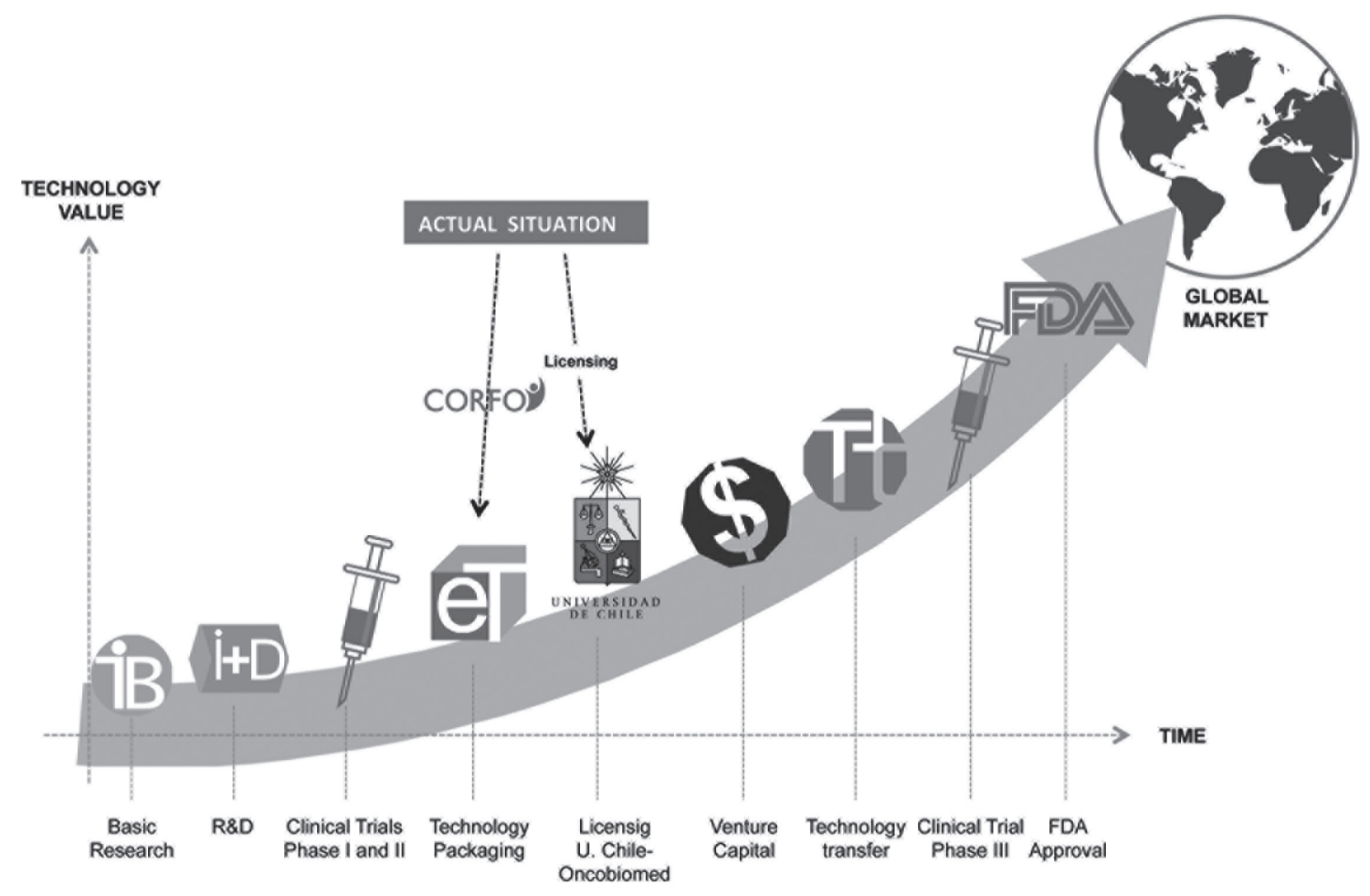

Figure 2. TAPCells technology current stage and valorization. Biomedical technologies need to pass different stages of development from basic research to clinical trials and sanitary authority approval. TAPCells technology is in an intermediate stage of development; a crucial milestone is the design and performing of phase III multi-center clinical trials. 
impact cancers such as gallbladder, gastric, and colon cancer; this will strongly expand the potential market for TAPCellsbased therapies and will confer a significant increase in the technological package value.

In our country, scientific research related to human health is mainly funded by the state agency CONICYT through the programs FONDECYT, FONDEF, and FONIS. Only in recent years have public funds derived from other institutions such as CORFO-Innova financed some projects in the area. In Chile, over 10 percent of the projects awarded by FONDECYT and FONDEF agencies correspond to health-related issues, however no public or private institutions fund particularly health research as occurs in developed countries. Despite the lack of coordination among agencies that finance innovation in Chile and the low preparation of academic institutions that deal with the issue, within a period of 10 years the system was able to support the development of a vaccine against melanoma and prostate cancer with a total investment of around three million dollars. While this institutional development constitutes a relatively successful example, it is also true that is an exception.

The reproduction of the TAPCells development experience requires identifying the key elements that drive the innovation process. These assumptions are not fulfilled in our country very often, so they should be strengthened by a public-private effort: (i) the existence of an innovative idea backed by solid scientific evidence, (ii) generation of academic and economic incentives that promote innovative drive, (iii) institutional support of state agencies that generate long-term policies that enable innovative project financing, and finally (iv) improved interest of the private sector to invest capital in risky long-term ventures.

\section{ACKNOWLEDGMENTS}

We thank Eugenio Rivas, Carlos Saffie and Raul Benavente for business-related advice, and Virna Salazar and Marisol Briones for administrative support. This study was supported by grants from the National Fund for Scientific and Technological Development (FONDECYT 1130320 FS, 1130324 ML), the Fund for the Promotion of Scientific and Technological Development (FONDEF D11I1036 FS and ML), The Chilean Economic Development Agency (CORFO 12IDL4-13655), and the Millennium Science Initiative from the Ministry for the Economy, Development and Tourism (P09/016-F).

\section{REFERENCES}

AGARWALA SS, GLASPY J, ODAY SJ, MITCHELL M, GUTHEIL J, WHITMAN E, GONZALEZ R, HERSH E, FEUN L, BELT R, MEYSKENS F, HELLSTRAND K, WOOD D, KIRKWOOD JM, GEHLSEN KR, NAREDI P. (2002) Results from a randomized phase III study comparing combined treatment with histamine dihydrochloride plus interleukin-2 versus interleukin-2 alone in patients with metastatic melanoma. J Clin Oncol 20:125-133.

AGUILERA R, SAFFIE C, TITTARELLI A, GONZÁLEZ FE, RAMÍREZ M, REYES D, PEREDA C, HEVIA D, GARCÍA T, SALAZAR L, FERREIRA A, HERMOSO M, MENDOZA-NARANJO A, FERRADA C, GARRIDO P, LÓPEZ MN, AND SALAZAR-ONFRAY F (2011) Heat Shock Induction of Tumor-Derived Danger Signals Mediate Rapid Monocyte Differentiation to Clinically Effective Dendritic Cells. Clin Cancer Res 17:2474-83.

ARDAVIN C, AMIGORENA S, REIS E, SOUSA C (2004) Dendritic Cells: Immunobiology and Cancer Immunotherapy. Immunity 20:17-23.
BAJETTA E, DI LEO A, ZAMPINO MG, SERTOLI MR, COMELLA G, BARDUAGNI M, GIANNOTTI B, QUEIROLO P, TRIBBIA G, BERNENGO MG, et al. (1994) Multicenter randomized trial of dacarbazine alone or in combination with two different doses and schedules of interferon alfa-2a in the treatment of advanced melanoma. J Clin Oncol 12:806-811.

BARTH RJ, JR., MULE JJ, SPIESS PJ, ROSENBERG SA (1991) Interferon gamma and tumor necrosis factor have a role in tumor regressions mediated by murine CD8+ tumor-infiltrating lymphocytes. J Exp Med 173:647-658.

BELL D, YOUNG JW, BANCHEREAU J (1999) Dendritic cells. Adv. Immunol 72:255-324.

BOCZKOWSKI D, NAIR SK, SNYDER D, GILBOA E (1996) Dendritic cells pulsed with RNA are potent antigen presenting cells in vitro and in vivo. J Exp Med 84:465-472.

BONASIO R, VON ANDRIAN UH (2006) Generation, migration and function of circulating dendritic cells. Curr Opin Immunol 18:503-511.

BOON T, CEROTTINI JC, VAN DEN EYNDE B, VAN DER BRUGGEN P, VAN PEL (1994) Tumor antigens recognized by T lymphocytes. Annu Rev Immunol 12:337-365.

BOON T, GAJEWSKI TF, COULIE PG (1995) From defined human tumor antigens to effective immunization? Immunol Today 16:334-336.

BRADFORD TJ, TOMLINS SA, WANG X, CHINNAIYAN AM (2006) Molecular markers of prostate cancer. Urol Oncol 24:538-51

BURNET FM (1957) Cancer: A biological approach. Br Med J 1:841-847.

CUENCA AG, DELANO MJ, KELLY-SCUMPIA KM, MORENO C, SCUMPIA PO, LAFACE DM, HEYWORTH PG, EFRON PA, MOLDAWER LL (2011) A paradoxical role for myeloid-derived suppressor cells in sepsis and trauma. Mol Med 17(3-4):281-292.

CURIEL TJ, COUKOS G, ZOU L, ALVAREZ X, CHENG P, MOTTRAM P, EVDEMON-HOGAN M, CONEJO-GARCIA JR, ZHANG L, BUROW M, ZHU Y, WEI S, KRYCZEK I, DANIEL B, GORDON A, MYERS L, LACKNER A, DISIS ML, KNUTSON KL, CHEN L, ZOU W (2004) Specific recruitment of regulatory $\mathrm{T}$ cells in ovarian carcinoma fosters immune privilege and predicts reduced survival. Nat Med 10(9):942-9.

DE IOANNES P, MOLTEDO B, OLIVA H, H, PACHECO R, DE IOANNES A. E., BECKER M.I. (2004) Hemocyanin of the molluscan Concholepas concholepas exhibits an unusual heterodecameric array of subunits. J Biol Chem 279:26134-42.

DIGHE AS, RICHARDS E, OLD LJ, SCHREIBER RD (1994) Enhanced in vivo growth resistance to rejection of tumor cells expressing dominant negative IFN $\gamma$ receptors. Immunity 1:447-456

DUDLEY ME, WUNDERLICH JR, YANG JC, SHERRY RM, TOPALIAN SL, RESTIFO NP, ROYAL RE, KAMMULA U, WHITE DE, MAVROUKAKIS SA, ROGERS LJ, GRACIA GJ, JONES SA, MANGIAMELI DP, PELLETIER MM, GEA-BANACLOCHE J, ROBINSON MR, BERMAN DM, FILIE AC, ABATI A, ROSENBERG SA (2005) Adoptive cell transfer therapy following non-myeloablative but lymphodepleting chemotherapy for the treatment of patients with refractory metastatic melanoma. J Clin Oncol 23(10):2346-57.

DURÁN C, SEGAL G, SALAZAR L, PEREDA C, FALCÓN C, TEMPIO F, AGUILERA R, GONZÁLEZ R, PÉREZ C,TITTARELLI A, CATALÁN D, SALAZAR-ONFRAY F, LÓPEZ MN (2012) The immunological and Clinical Outcomes of DC-Vaccinated Melanoma Patients Are Associated with Increased Th1/Th17 and Reduced Th3 Cytokine Responses. Cancer Immunol Immunother 62:761-72

ESCOBAR A, LÓPEZ M, SERRANO A, RAMIREZ M, PÉREZ C, AGUIRRE A, GONZÁLEZ R, ALFARO J, LARRONDO M, FODOR M, FERRADA C, SALAZAR-ONFRAY F. (2005) Dendritic cell immunizations alone or combined with low doses of interleukin-2 induce specific immune responses in melanoma patients. Clin Exp Immunol 142:555-68.

FALKSON CI, IBRAHIM J, KIRKWOOD JM, COATES AS, ATKINS MB, BLUM RH. (1998) Phase III trial of dacarbazine versus dacarbazine with interferon alpha- $2 b$ versus dacarbazine with tamoxifen versus dacarbazine with interferon alpha- $2 b$ and tamoxifen in patients with metastatic malignant melanoma: an Eastern Cooperative Oncology Group study. J Clin Oncol 16:1743-1751.

FERLAY J, SHIN HR, BRAY F, FORMAN D, MATHERS C AND PARKIN DM (2010) GLOBOCAN 2008 v2.0, Cancer Incidence and Mortality Worldwide: IARC CancerBase No. 10 [Internet]. Lyon, France: International Agency for Research on Cancer. Available from http:/ / globocan.iarc.fr

FILIPAZZI P, VALENTI R, HUBER V, PILLA L, CANESE P, IERO M, CASTELLI C, MARIANI L, PARMIANI G, RIVOLTINI L (2007) Identification of a new subset of myeloid suppressor cells in peripheral blood of melanoma patients with modulation by a granulocyte- 
macrophage colony-stimulation factor-based antitumor vaccine. J Clin Oncol 25(18):2546-2553.

FUESSEL S, MEYE A, SCHMITZ M, ZASTROW S, LINNÉ C, RICHTER $\mathrm{K}$, LÖBEL B, HAKENBERG OW, HOELIG K, RIEBER EP, WIRTH MP (2006) Vaccination of hormone-refractory prostate cancer patients with peptide cocktail-loaded dendritic cells: results of a phase I clinical trial. Prostate 66:811-821.

GARNICK MB (1993) Prostate cancer: Screening, diagnosis, and management. Ann Int Med 118:804-18

GOSS PE, LEE BL, BADOVINAC-CRNJEVIC T, et al. (2013) Planning cancer control in Latin America and the Caribbean. Lancet Oncol 14:391-436.

GUSTAFSON MP, LIN Y, NEW KC, BULUR PA, O'NEILL BP, GASTINEAU DA, DIETZ AB (2010) Systemic immune suppression in glioblastoma: the interplay between CD14+HLA-DRlo/neg monocytes, tumor factors, and dexamethasone. Neuro Oncol. 12(7):631-44.

HART DN (1997) Dendritic cells: Unique leukocyte populations, which control the primary immune response. Blood 90:3245-3287.

HAYAT MJ, HOWLADER N, REICHMAN ME, EDWARDS BK (2007) Cancer statistics, trends, and multiple primary cancer analyses from the Surveillance, Epidemiology, and End Results (SEER) Program. Oncologist 12:20-37.

HERSEY P, MENZIES SW, HALLIDAY GM, et al. (2004) Phase I/II study of treatment with dendritic cell vaccines in patients with disseminated melanoma. Cancer Immunol Immunother 53:125-134

HODI FS, ODAY SJ, MCDERMOTT DF, et al. (2010) Improved survival with Ipilimumab in patients with metastatic melanoma. N Engl J Med 363:711-23.

IMS INSTITUTE FOR HEALTHCARE INFORMATICS (2012) The use of medicines in the United States: Review of 2011, Parsippany, NJ: Author. Retrieved from http://freelist.mcol.com / $\mathrm{t} / 21052373 / 40724031 / 1066556 / 0 /$

ITOH K, PLATSOUCAS DC, BALCH CM (1988) Autologous tumorspecific cytotoxic $\mathrm{T}$ lymphocytes in the infiltrate of human metastatic melanomas: activation by interleukin 2 and autologous tumor cells and involvement of the T cell receptor. J Exp Med 168:1419-1441.

JEMAL A, SIEGEL R, WARD E, HAO Y, XU J, MURRAY T, THUN MJ. (2008) Cancer statistics, 2008. CA Cancer J Clin 58:71-96.

KAPLAN DH, SHANKARAN V, DIGHE AS, STOCKERT E, AGUET M, et al. (1998) Demonstration of an interferon $\gamma$ - dependent tumor surveillance system in immunocompetent mice. Proc Natl Acad Sci USA 95:7556-7561

KEILHOLZ U, PUNT CJ, GORE M, KRUIT W, PATEL P, LIENARD D, THOMAS J, PROEBSTLE TM, SCHMITTEL A, SCHADENDORF D, VELU T, NEGRIER S, KLEEBERG U, LEHMAN F, SUCIU S, EGGERMONT AM (2005) Dacarbazine, cisplatin, and interferon-alfa-2b with or without interleukin-2 in metastatic melanoma: a randomized phase III trial (18951) of the European Organisation for Research and Treatment of Cancer Melanoma Group. J Clin Oncol 23:6747-6755.

KNUTH A, WÖLFEL T, MEYER ZUM BUSCHENFELDE P (1992) T cell responses to human malignant tumours. Cancer Surv 13:39-52.

LENS MB, DAWES M. (2004) Global perspectives of contemporary epidemiological trends of cutaneous malignant melanoma. Br J Dermatol. 150:179-85.

LIN Y, GUSTAFSON MP, BULUR PA, GASTINEAU DA, WITZIG TE, DIETZ AB (2011) Immunosuppressive CD14+HLA-DR(low)/- monocytes in B-cell non-Hodgkin lymphoma. Blood 117(3):872-881.

LÓPEZ M N, PEREDA C, SEGAL G, MUÑOZ L, AGUILERA R, GONZÁLEZ FE., ESCOBAR A, GINESTA A, REYES D, GONZÁLEZ R, LARRONDO M, COMPÁN A, FERRADA C, SALAZAR-ONFRAY F (2009) Prolonged survival of dendritic cell-vaccinated melanoma patients correlates with tumor-specific delayed type IV hypersensitivity response and reduction of tumor growth factor $\beta$-expressing T cells. J Clin Oncol 27:945-52.

LÓPEZ M, AGUILERA R, PÉREZ C, MENDOZA-NARANJO A, PEREDA C, RAMÍREZ M, FERRADA C, AGUILLON JC, SALAZAR-ONFRAY $\mathrm{F}$ (2006) The role of regulatory $\mathrm{T}$ lymphocytes in the induced immune response mediated by biological vaccines. Immunobiology 211:127-36.

LÓPEZ M, ESCOBAR A, ALFARO J, FODOR M, LARRONDO M, FERRADA C, SALAZAR-ONFRAY F. (2004) Advances in cellular immunotherapy for malignant melanoma Rev Med Chil 132:1115-26

LÓPEZ MN, ESCOBAR A, ALFARO J, FODOR M, LARRONDO M, FERRADA C, SALAZAR-ONFRAY F (2004) Advances in cellular immunotherapy for malignant melanoma. Rev Med Chil 132:1115-26.

MA C, ARMSTRONG A. (2013) Severe Adverse Events from the Treatment of Advanced Melanoma: A Systematic Review of Severe Side EffectsAssociated with Ipilimumab, Vemurafenib, Interferon Alfa-2b, Dacarbazine, and Interleukin-2. J Dermatolog Treat PMID: 23763243 (in press).
MACKENSEN A, MEIDENBAUER N, VOGL S, LAUMER M, BERGER J, ANDREESEN R (2006) Phase I study of adoptive T-cell therapy using antigen-specific CD8 $+\mathrm{T}$ cells for the treatment of patients with metastático melanoma. J Clin Oncol 24:5060-5069.

MATZINGER P (2007) Friendly and dangerous signals: is the tissue in control? Nat Immunol 8:11-13

MU LJ, KYTE JA, KVALHEIM G, AAMDAL S, DUELAND S, HAUSER M, HAMMERSTAD H, WAEHRE H, RAABE N, GAUDERNACK G (2005) Immunotherapy with allotumour mRNA-transfected dendritic cells in androgen-resistant prostate cancer patients. Br J Cancer 93: 749-756.

NAGAYAMA H, SATO K, MORISHITA M et al. (2003) Results of a phase I clinical study using autologous tumour lysate-pulsed monocyte-derived mature dendritic cell vaccinations for stage IV malignant melanoma patients combined with low dose interleukin-2. Melanoma Res 13:521-530

NESTLE FO, ALIJAGIC S, GILLIET M et al. (1998) Vaccination of melanoma patients with peptide- or tumor lysatepulsed dendritic cells. 1998. Nat Med 74:328-332.

NIEBOER P, DE VRIES EG, MULDER NH, VAN DER GRAAF WT (2005) Relevance of high-dose chemotherapy in solid tumours. Cancer Treat Rev 31:210-25.

OROURKE MG, JOHNSON M, LANAGAN C (2003) Durable complete clinical responses in a phase I/II trial using an autologous melanoma cell/dendritic cell vaccine. Cancer Immunol Immunother 52:387-395.

PAGLIA P, CHIODONI C, RODOLFO M, COLOMBO MP (1996) Murine dendritic cells loaded in vitro with soluble protein prime cytotoxic $\mathrm{T}$ lymphocytes against tumor antigen in vivo. J Exp Med 183:317-322

PAIN S (2002) Dr Coley's Famous Fever. New Scientist. "Spontaneous regression: a hidden treasure buried in time by Hoption Cann". Medical Hypotheses 58:115.

PERANZONI E, ZILIO S, MARIGO I, DOLCETTI L, ZANOVELLO P MANDRUZZATO S, BRONTE V (2010) Myeloid-derived suppressor cell heterogeneity and subset definition. Curr Opin Immunol 22(2):238-244.

PORGADOR A, GILBOA E (1995) Bone marrow-generated dendritic cells pulsed with a class I restricted peptide are potent inducers of cytotoxic T lymphocytes. J Exp Med 182:255-260

POSCHKE I, MAO Y, ADAMSON L, SALAZAR-ONFRAY F, MASUCCI G, KIESSLING R. (2012) Myeloid-derived suppressor cells impair the quality of dendritic cell vaccines. Cancer Immunol Immunother 61(6):827-38.

POWELL DJ JR, DUDLEY ME, HOGAN KA, WUNDERLICH JR, ROSENBERG SA (2006) Adoptive transfer of vaccine induced peripheral blood mononuclear cells to patients with metastatic melanoma following lymphodepletion. J Immunol 177:6527-6539.

REYES D, SALAZAR L, ESPINOZA E, PEREDA C, CASTELLÓN E, VALDEVENITO R, HUIDOBRO C, BECKER MI, LLADSER A, LÓPEZ MN, SALAZAR-ONFRAY F (2013) Tumor Cell Lysate Loaded-Dendritic Cell Vaccine Induces Biochemical And Memory Immune Response In Castration-Resistant Prostate Cancer Patients. Brit J. Cancer 109: 1488-97.

RIBAS A, CAMACHO LH, LÓPEZ-BERENSTEIN G et al. (2005) Antitumor activity in melanoma and anti-self responses in a phase I trial with the anti-cytotoxic T lymphocyte-associated antigen 4 monoclonal antibody CP-675, 206. J Clin Oncol 23:8968-8977.

RIDGWAY D. The first 1000 dendritic cell vaccines. Cancer Invest. 2003; 21: 873-886.

RINI BI, FONG L, WEINBERG V, KAVANAUGH B, SMALL EJ (2006) Clinical and immunological characteristics of patients with serologic progression of prostate cancer achieving long-term disease control with granulocyte-macrophage colony-stimulating factor. J Urol 175:2087-91.

ROSENBERG SA, RESTIFO NP, YANG JC, MORGAN RA, DUDLEY ME (2008) Adoptive cell transfer: a clinical path to effective cancer immunotherapy. Nat Rev Cancer 8:299-308.

ROSENBERG SA, YANG JC, SCHWARTZENTRUBER DJ et al. (1998) Immunologic and therapeutic evaluation of a synthetic peptide vaccine for the treatment of patients with metastatic melanoma. Nat Med 4:321-327.

SAKAGUCHI, N. (2005) Naturally arising Foxp3-expressing CD25+CD4+ regulatory $\mathrm{T}$ cells in immunologic tolerance to self and non-self. Nat. Immunol 6: 345-352.

SALAZAR-ONFRAY F, LÓPEZ MN, MENDOZA-NARANJO A. (2007) Paradoxical effects of cytokines in tumor immune surveillance and tumor immune escape. Cytokine Growth Factor Rev 18:171-82.

SALAZAR-ONFRAY F, LÓPEZ MN, PEREDA C, AGUILERA R, ESCOBAR A (2007) Método para generar vacunas que estimulen el sistema inmune que comprende inducir cédulas mononucleares de sangre periférica A que se diferencien a APC, para luego separar dichas APC y mezclarlas con adyuvantes; Extracto de Células Tumorales; y Composición farmacéutica que comprende APC. Solicitud patente de invención $\mathrm{N}^{\mathrm{o}}$ 
2825-2007. Instituto Nacional de Propiedad Industrial (INAPI) de Chile. Internacional 2008. PCT / EP2008/062909

SAUTER B, ALBERT ML, FRANCISCO L, LARSSON M, SOMERSAN S, BHARDWAJ N (2000) Consequences of cell death: exposure to necrotic tumor cells, but not primary tissue cells or apoptotic cells, induces the maturation of immunostimulatory dendritic cells. J Exp Med 191:423-434

SCHADENDORF D, UGUREL S, SCHULER-THURNER B (2006) Dacarbazine versus vaccination with autologous peptide-pulsed dendritic cells in first-line treatment of patients with metastatic melanoma: a randomized phase III trial of the DC study group of the DeCOG. Annals of Oncology 17:563-570.

SCHER HI, STEINECK G, KELLY WK (1995) Hormone-refractory (D3) prostate cancer: refining the concept. Urology 46:142-48

SEMENIUK RC, VENNER PM, NORTH S (2006) Prostate-specific antigen doubling time is associated with survival in men with hormonerefractory prostate cancer. Urology 68:565-569.

SHULER G, SHULER-THURNER B, STEINMAN RM (2003) The use of dendritic cells in cancer immunotherapy. Curr OpinImmunol 15:138-147.

SVANE IG, SOOT MT, BUUS S, JOHNSEN HE (2003) Clinical application of dendritic cells in cancer vaccination therapy. APMIS 111:818-834.

TANNOCK IF, DE WIT R, BERRY WR, HORTI J, PLUZANSKA A, CHI KN, OUDARD S, THÉODORE C, JAMES ND, TURESSON I, ROSENTHAL MA, EISENBERGER MA; TAX 327 INVESTIGATORS (2004) Docetaxel plus prednisone or mitoxantrone plus prednisone for advanced prostate cancer. N Engl J Med 351:1502-12.

THOMAS L (1982) On immunosurveillance in human cancer. Yale J Biol Med 55:329-333.

TITTARELLI A, GONZÁLEZ FE, PEREDA C, MORA G, MUÑOZ L, SAFFIE C, GARCÍA T, DÍAZ D, FALCÓN C, HERMOSO M, LÓPEZ MN, SALAZAR-ONFRAY F (2012) Toll-Like Receptor 4 gene polymorphism influences dendritic cell in vitro function and clinical outcomes in vaccinated melanoma patients. Cancer Immunol Immunother 61:2067-77.

TJOA BA, SIMMONS SJ, ELGAMAL A, ROGERS M, RAGDE H, KENNY GM, TROYCHAK MJ, BOYNTON AL, MURPHY GP (1999) Follow-up evaluation of a phase II prostate cancer vaccine trial. Prostate 40:125-129.

TOPALIAN SL, SOLOMON D, ROSENBERG SA. (1989) Tumor-specific cytolysis by lymphocytes infiltrating human melanomas. J Immunol 142:3714-3725.

TREFZER U, HERBERTH G, WOHLAN K et al. (2005) our-dendritic hybrid cell vaccination for the treatment of patients with malignant melanoma: immunological effects and clinical results. Vaccine 23:2367-2373

VIRET C, DAVODEAU F, GUILLOUX Y, BIGNON JD, SEMANA G, BREATHNACH R, JOTEREAU F (1993) Recognition of shared melanoma antigen by HLA-A2-restricted cytolytic T cell clones derived from human tumor-infiltrating lymphocytes. Eur J Immunol 23:141-6.

VOGEL CL, COBLEIGH MA, TRIPATHY D, GUTHEIL JC, HARRIS LN, FEHRENBACHER L, SLAMON DJ, MURPHY M, NOVOTNY WF, BURCHMORE M, SHAK S, STEWART SJ, PRESS M (2002) Efficacy and safety of trastuzumab as a single agent in first-line treatment of HER2overexpressing metastatic breast cancer. J Clin Oncol 20:719-726.

VUK-PAVLOVIC S, BULUR PA, LIN Y, QIN R, SZUMLANSKI CL, ZHAO $X$, DIETZ AB (2010) Immunosuppressive CD14+HLA-DRlow/monocytes in prostate cancer. Prostate 70(4):443-455.

WEINER LM (2008) Cancer immunotherapy, the endgame begins. N Engl J Med 358:2664-5.

WOLF AM, WOLF D, STEURER M, GASTL G, GUNSILIUS E, GRUBECKLOEBENSTEIN B (2003) Increase of regulatory T cells in the peripheral blood of cancer patients. Clin Cancer Res 9(2):606-12.

YOUN JI, GABRILOVICH DI (2010) The biology of myeloid-derived suppressor cells: the blessing and the curse of morphological and functional heterogeneity. Eur J Immunol 40(11):2969-2975. 